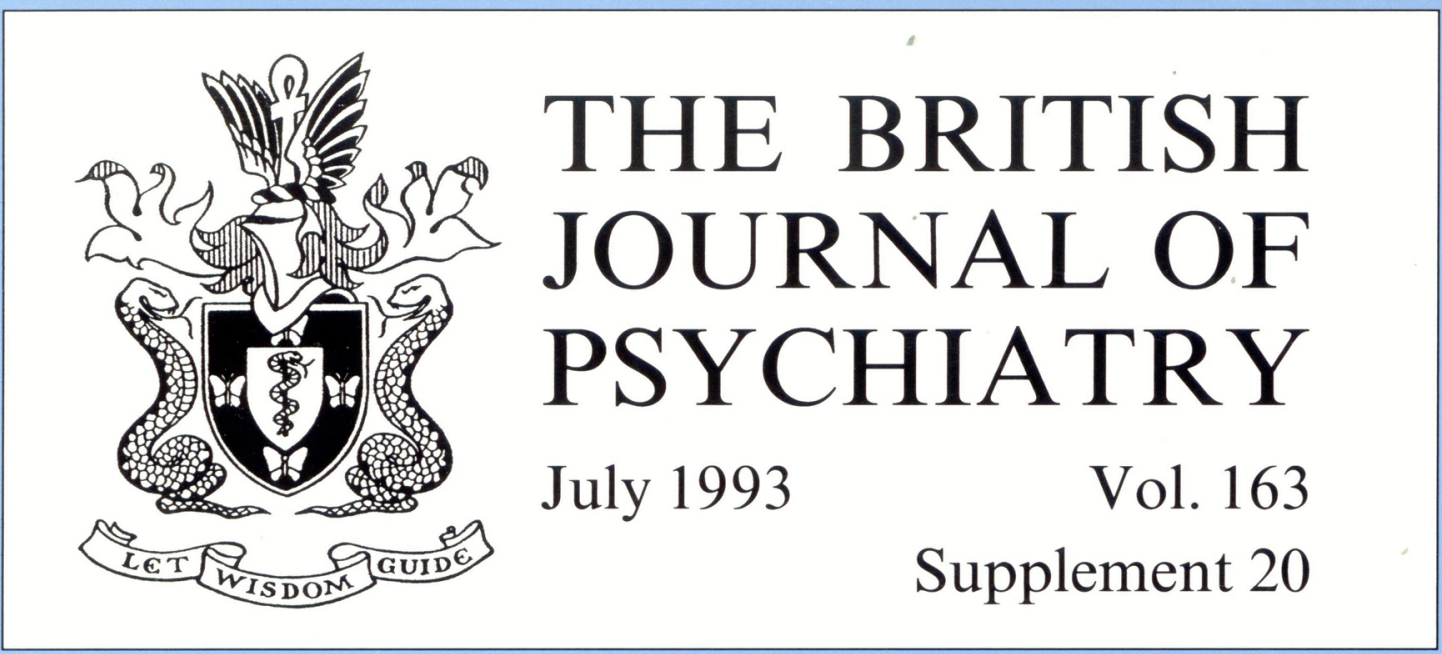

\title{
The Economic Evaluation of Antidepressant Drug Therapy
}

Edited by

Donald Eccleston

Published by The Royal College of Psychiatrists 


\title{
THE BRITISH \\ JOURNAL OF PSYCHIATRY
}

\section{The Economic Evaluation of Antidepressant Drug Therapy}

\author{
Edited by \\ DONALD ECCLESTON
}

Publication of this Supplement was made possible by the kind help of E. Merck Pharmaceuticals 


\section{The British Journal of Psychiatry}

Published monthly. Founded in 1853 as the Asylum Journal and known as the Journal of Mental Science from 1855 to 1963

\section{Editor: Hugh Freeman}

Senior Associate Editor

Alan Kerr

\section{Associate Editors}

Dora Black, Sidney Crown, Julian Leff, Sir Martin Roth,

Peter Tyrer

\section{Assistant Editors}

Mohammed Abou-Saleh, German Berrios, Peter Bruggen, Patricia Casey,

Alexander Kellam, Stuart Montgomery, Catherine Oppenheimer, Ian Pullen, Rosalind Ramsay, Henry Rollin, Oliver Russell, George Stein, Digby Tantam, Greg Wilkinson, Stephen Wilson

\section{Corresponding Editors}

Sidney Bloch (Australia), Patrice Boyer (France), Brian Cooper (Germany), E. L. Edelstein (Israel), Václav Filip (Czechoslovakia), Harold Merskey (Canada), Paul Mullen (New Zealand), Ahmed Okasha (Egypt), Toma Tomov (Bulgaria), John Tsiantis (Greece), Richard Warner (USA)

\section{Publications Manager}

Dave Jago

\section{Scientific Editor}

Ralph Footring

\section{Bulletin Manager \\ Elaine Millen}

@ ${ }^{\mathrm{TM}}$ The paper used in this publication meets the minimum requirements of American National Standard for Information Sciences - Permanence of Paper for Printed Library Materials ANS1 Z39. 48-1984.

Typeset by Dobbie Typesetting, Tavistock, Devon. Printed by Henry Ling Ltd, The Dorset Press, 23 High East Street, Dorchester, Dorset DT1 1HD (tel. 0305-251 066).

(C) 1993 The Royal College of Psychiatrists

\section{Assistant Scientific Editor \\ Marina Holmes}

\section{Editorial Assistants}

Judy Ashworth,

Julia Burnside

\section{Subscriptions}

Non-members of the College should contact the British Journal of Psychiatry Subscription Department, The Royal Society of Medicine, 1 Wimpole Street, London W1M 8AE. Annual subscription rates for 1993 (12 issues post free) are as follows:

UK and Europe: institutions $£ 140$, individuals $£ 123$

US: institutions $\$ 295$, individuals $\$ 200$

Elsewhere: institutions $£ 165$, individuals $£ 130$

Payment should be made out to the British Journal of Psychiatry.

Queries from non-members about missing or faulty copies should be addressed within six months to the same address; similar queries from College members should be addressed to the Registration Department, The Royal College of Psychiatrists, 17 Belgrave Square, London SW1X 8PG.

\section{Advertising}

Correspondence and copy should be addressed to Peter T. Mell, Advertising Manager, PTM Publishers Ltd, 282 High Street, Sutton, Surrey SM1 1PQ (tel. 081-642 0162, fax 081-643 2275).

US Mailing Agents: Mercury Airfreight International Ltd, Inc., 2323 Randolph Avenue, Avenel, NJ 07001.

Back issues published before 1988 may be purchased from William Dawson \& Sons Ltd, Cannon House, Folkestone, Kent, England (tel. 0303-850-101). 


\section{Contents}

List of contributors

Introduction

DONALD ECCLESTON

Cost management: the economist's viewpoint

ALAN MAYNARD

Diagnosis and treatment of depression in general practice

PAUL FREELING

Side-effects of antidepressants

JOHN COOKSON

Comparisons of clinical efficacy

I. N. FERRIER

Suicide in depressed patients: medico-legal issues

R. J. DALY

Debits and credits in the management of depression JOHN A. HENRY

Conclusion

GEORGE BEAUMONT

40 